REVIEW

\title{
RET/PTC rearrangement in benign and malignant thyroid diseases: a clinical standpoint
}

\author{
Vincenzo Marotta, Anna Guerra ${ }^{1}$, Maria Rosaria Sapio ${ }^{1}$ and Mario Vitale ${ }^{1}$ \\ Department of Clinical and Molecular Endocrinology and Oncology, University Federico II, Naples, Italy and ${ }^{1}$ School of Medicine, University of Salerno, \\ Via Allende, 84081 Baronissi, Salerno, Italy
}

(Correspondence should be addressed to M Vitale; Email: mavitale@unisa.it)

\begin{abstract}
Cytological examination of fine needle aspiration biopsy is the primary means for distinguishing benign from malignant nodules. However, as inconclusive cytology is very frequent, the introduction of molecular markers in the preoperative diagnosis of thyroid nodules has been proposed in recent years. In this article, we review the clinical implications of preoperative detection of rearrangements of the RET gene (RET/papillary thyroid carcinoma (PTC)) in thyroid nodules. The prevalence of RET/PTC in PTC depends on the histological subtypes, geographical factors, radiation exposure, and detection method. Initially, RET/PTC was considered an exclusive PTC hallmark and later it was also found sporadically in benign thyroid lesions. More recently, the very sensitive detection methods, interphase fluorescence in situ hybridization (FISH) and Southern blot on RT-PCR amplicons, demonstrated that the oligoclonal occurrence of RET rearrangement in benign thyroid lesions is not a rare event and suggested that it could be associated with a faster enlargement in benign nodules. For this reason, RET/PTC cannot be considered as an absolute marker of PTC, and its diagnostic application must be limited to assays able to distinguish between clonal and oligoclonal expression. Detection of RET/PTC by quantitative assays will be useful for diagnostic purposes in cytology specimens when a precise cutoff will be fixed in a clinical setting. Until that time, less sensitive RET/PTC detection methods and FISH analysis remain the most appropriate means to refine inconclusive cytology. Future studies with a long follow-up will further clarify the clinical significance of low level of RET rearrangements in benign nodules.
\end{abstract}

European Journal of Endocrinology 165 499-507

\section{Introduction}

Palpable nodules of the thyroid gland are a common clinical occurrence. The majority of such lesions are benign in nature. The differential diagnosis between benign and malignant nodules is based on cytological evaluation of thyroid cells obtained by fine needle aspiration cytology (FNAC), stained by May-GrunwaldGiemsa or Papanicolaou methods $(1,2)$. However, a relevant number of thyroid nodules exhibit borderline morphological signs of papillary thyroid carcinoma (PTC) representing a difficult diagnostic challenge. Many markers of malignancy have been investigated in the attempt to improve FNAC accuracy (3-6). Among the molecular markers of PTC, oncogenes with a pathogenetic role in the mechanism of thyroid cell transformation are most promising. Rearrangements of the RET gene in PTC (RET/PTC) was one of the first human oncogene discovered and was the first oncogene proposed as a marker for this tumor (7). The carcinogenetic potential of RET/PTC and its expression in different tumors have been extensively studied by different methods in tissues and in cytology specimens. Early studies concluded that RET/PTC was responsible for the development of thyroid cancer and was totally restricted to PTC $(8-10)$. This claimed specificity as a PTC marker raised the possibility for its clinical application in those situations where the conventional cytology yields inconclusive results (11-16). However, the initial enthusiasm was tempered by the finding of RET/PTC in benign lesions including Hashimoto's thyroiditis (HT) and adenomas (17-20). The finding that RET/PTC expression is not an absolute PTC marker raises concerns on its clinical utility in inconclusive FNAC. Moreover, the finding that RET rearrangements can occur only in a fraction of the cells in some PTC raises the alternative hypothesis that RET/PTC may also be a common secondary event in the process of thyroid carcinogenesis (21). The subclonal occurrence of RET rearrangement in PTC can influence the sensitivity of some methods and might explain why the reported prevalence of RET/PTC in papillary carcinomas varies in different studies from 0 to $87 \%$ $(22,23)$. Very recent studies demonstrated that RET rearrangement in benign thyroid nodules is not 
an uncommon occurrence and suggested that its presence could be associated with a faster nodular enlargement (24-26).

In this article, we review the clinical implications of RET/PTC detection in preoperative diagnosis of thyroid nodules and the recent advances in the clinical significance of this oncogene in benign nodules.

\section{RET rearrangements: RET and the other genes involved}

The RET (rearranged during transfection) proto-oncogene is located at chromosome 10q11.2 and encodes a cell membrane receptor tyrosine kinase. It was discovered in 1985 as a gene rearranged in the procedure of an NIH3T3 transfection assay (27). The RET proto-oncogene is a main component of the signaling pathway, activated by the glial cell linederived neurotropic factor family ligands, and is implicated in the development of kidney and enteric nervous system $(28,29)$. The RET protein comprises an extracellular domain with ligand-binding function composed of four cadherin-like sites, followed by a cysteine-rich loop, a single transmembrane region, and an intracellular domain containing the juxtamembrane domain and the tyrosine kinase domain (30). In the thyroid gland, RET protein is strongly expressed in parafollicular C-cells consistently with its role in the development of neural crest-derived structures (29). Although RET mRNA has been documented in follicular cell-derived thyroid tumors, to date, RET mRNA or protein has never been clearly detected in thyroid follicular cells (31). In some PTCs, the tyrosine kinase domain of RET is fused with an heterologous gene that provides the promoter and the $5^{\prime}$-coding region $(32)$. The product of this rearrangement is a chimeric oncogene named RET/papillary thyroid carcinoma (RET/PTC). Since the original report, at least 11 types of RET/PTC variants have been isolated (32). Most of these rearrangements are between RET on chromosome 10 and genes located on different chromosomes. By contrast, RET/PTC1 and RET/PTC 3 are intrachromosomal paracentric inversions because the genes involved H4 and RFG (also designated ELE1/ARA7O/NCOA4) are also all located on chromosome $10(32,33)$. RET/PTC1 and RET/PTC3 account for the vast majority of the variants, while the others are very rare and have little clinical significance. The chimeric RET/PTC protein generated by the genetic recombinations lacks the transmembrane domain and the extracellular regulatory region of RET but retains the coiled-coil domains in the RET partner coding sequences, necessary for the dimerization process. This determines the cytoplasmic location of the chimeric protein, its ligandindependent dimerization, and its autophosphorylation at residues 1015 and 1062 responsible for the oncogenic activity of the RET/PTC chimera (34).

\section{Methods of detection for RET/PTC rearrangements}

Detection of the RET/PTC protein in cytology or tissue samples by immunohistochemistry (IHC) would be desirable, so that the pathologist could search for RET/PTC in surgical and preoperative cytological samples and at the same time observe the morphology of the sample. In different studies, commercially available or personally produced antibodies for the carboxy-terminal part of RET or for the phosphorylated tyrosine 1062 of RET were used to detect the presence of the tyrosine kinase domain. This method is based on the assumption that wild-type RET is not expressed in PTC or if expressed it is not activated and has the advantage of detecting all RET rearrangements (34-36). However, RET immunoreactivity in the cytoplasm of PTC is often weak and largely variable, also within the same tumor, making the interpretation of the results challenging. Moreover, very recently, wild-type RET expression was demonstrated by IHC and RT-PCR in PTCs in Kuwait (37).

Conventional PCR from genomic DNA is not suitable to detect RET/PTC because the rearrangement of RET occurs immediately upstream of its tyrosine kinaseencoding domain, whereas the fused gene is truncated at different points in different tumors. Thus, hundreds or thousands base-long intronic sequences separate the exons of the fused genes.

Conversely, cDNA can be analyzed by RT-PCR using primers annealing to the RET-exon 12 and the exons 1 and 6 of H4 or ELE1 respectively. Then, the PCR products are electrophoresed on a $1.5 \%$ agarose gel and visualized by ethidium bromide staining. This method to detect RET/PTC1 and RET/PTC3 recombinations is easy to perform and accurate. However, the low and heterogeneous expression of RET recombinants limits the application of this method and produces a number of false negative results, as demonstrated by comparative analysis of RET/PTC detection by RT-PCR and other methods in the same cytology samples $(22,24)$. Detection of RET rearrangements become much more robust when the RT-PCR products are visualized by Southern blot using oligonucleotide probes specific for RET/PTC1 or RET/PTC3 (22). Detection of RT-PCR products by Southern blot compared with ethidium bromide resulted in a 2.5 - to 5 -fold increased sensitivity $(24,35)$. Moreover, the step of hybridization with specific probes ensures a higher specificity compared with RT-PCR alone. Another method of detection is quantitative real-time RT-PCR. Amplification is achieved by a high number of cycles of amplification followed by post-PCR fluorescence melting curve analysis. Detection of RET/PTC1 and RET/PTC3 rearrangement by amplification using real-time RT-PCR did not demonstrate to be more sensitive than RT-PCR (22). However, in this method also, the hybridization step with specific probes increases the specificity and reduces the risk of false positive results. 
Dual-color interphase fluorescence in situ hybridization (FISH) is based on the microscopic observation of nuclei with overlapping red and green FISH signals (wild-type RET), or split FISH signals (rearranged RET) if one DNA probe maps the RET locus, while the other probe maps a sequence distal to RET. Alternatively, the probes can map the RET locus or the recombinant genes, and in this case, an overlapping signal indicates a rearranged RET gene. This is a time-consuming and laborious method that requires the observation of a large number of nuclei by an experienced operator. However, this method provides important information on the percentage of cells harboring the RET rearrangement and on its clonal/non-clonal occurrence $(21,22)$. More recently, automated interphase FISH was successfully applied to detect RET/PTC in PTC primary cultures, a method that, suitably modified for clinical practice, could allow the analysis of a larger number of cells per sample and overcome a possible bias of the operator (38).

\section{RET/PTC in thyroid cancer}

RET rearrangements are an exclusive occurrence of thyroid gland. A possible explanation for this restriction is that contiguity between RET and the recombinant genes occurs in nuclei of thyroid cells but not in other cell types (39). After its initial discovery in 1985, a large survey conducted in the following decades evidenced the frequent occurrence of RET/PTC in PTC and its sporadic oligoclonal occurrence in benign thyroid lesions. The estimated prevalence of RET rearrangement in PTC is highly variable among different studies (Table 1). A crucial factor responsible for this wide variability is the detection method. Zhu et al. (22) searched for RET/PTC1 and RETPTC3, the two main rearrangements of RET, in a cohort of 65 tumor samples from PTC patients using different techniques. They found a broad variability in the prevalence of RET/PTC rearrangement as a result of the different sensitivity of the detection methods. RET rearrangements were detected in 12 tumors by real-time LightCycler RT-PCR, in 14 by RT-PCR, and in 26 by the more sensitive Southern blot on RT-PCR products. These striking differences reflect the ability of the methods to detect RET/PTC when present in a small proportion of neoplastic cells within the tumor. Another important factor responsible for the variable prevalence of RET rearrangements among different studies of PTC is their tumor subtype composition. PTC is a heterogeneous tumor including very frequent variants such as classic PTC (cPTC) and follicular PTC (fvPTC), and some uncommon PTC variants such as tall-cell PTC (tcPTC), diffuse-sclerosing, columnar-cell, Hurthle-cell, cribriform, and solid variants (40). The reported prevalence of RET rearrangements in CPTC was generally higher than that in fvPTC (Table 2). RET/PTC, mostly the RET/PTC1, has been detected in a relevant percentage of
Table 1 Prevalence of RET rearrangements in sporadic PTC in different studies. Data are presented as sample numbers and (\%). RT-PCR was visualized by ethidium bromide.

\begin{tabular}{|c|c|c|c|c|}
\hline & RT-PCR & $\begin{array}{l}\text { SB on } \\
\text { RT-PCR }\end{array}$ & Q-PCR & FISH \\
\hline Ishizaka et al. (17) & & $1 / 11(9)$ & & \\
\hline Zou et al. (68) & & $1 / 40(3)$ & & \\
\hline Nikiforov et al. (45) & & $11 / 17$ (65) & & \\
\hline Lam et al. (69) & & & & $17 / 40(43)$ \\
\hline Tallini et al. (50) & $17 / 28(61)$ & & & \\
\hline Sugg et al. (35) & & $51 / 84(61)$ & & \\
\hline Mayr et al. (70) & 8/99 (8) & & & \\
\hline Cinti et al. (59) & & & & $13 / 69(19)$ \\
\hline Sheils et al. (71) & $12 / 50(24)$ & & & \\
\hline Fenton et al. (72) & $15 / 33(45)$ & & & \\
\hline Chua et al. (73) & & $37 / 47$ (79) & & \\
\hline Elisei et al. (18) & & $21 / 47$ (45) & & \\
\hline Puxeddu et al. (74) & & $13 / 48(27)$ & & \\
\hline Rhoden et al. (75) & & & 18/25 (72) & \\
\hline Zhu et al. (22) & $14 / 65$ (22) & $26 / 65(40)$ & $12 / 65$ (18) & $14 / 65(22)$ \\
\hline Rhoden et al. (54) & & & 25/34 (74) & $24 / 26(92)$ \\
\hline Frasca et al. (74) & 2/50 (4) & & & \\
\hline Guerra et al. (24) & $8 / 50(16)$ & $18 / 50(36)$ & & \\
\hline
\end{tabular}

SB on RT-PCR, Southern blot on RT-PCR; Q-PCR, real-time quantitative RT-PCR

Hurthle-cell variant PTC, in the cribriform variant, which is typically associated with familial adenomatous polyposis, and in hyalinizing trabecular tumor, a borderline thyroid neoplasm with many histological features similar to PTC (41-44).

Ionizing radiations are known to be a relevant cause for genetic alteration and carcinogenesis because they are particularly effective in inducing DNA double-strand breaks. The role of ionizing radiations in thyroid carcinogenesis has been extensively studied in Belarus, Ukraine, and parts of the Russian Federation, which have been affected by the Chernobyl accident. These studies evidenced that the Chernobyl accident resulted in a dramatic increase in the number of thyroid cancers of PTC type with a frequency of rearrangements of the RET proto-oncogene higher than that in sporadic PTC $(45,46)$. The association of RET rearrangements with radiation exposure was sustained by the observation that the incidence of PTCs is severely increased in radiocontaminated areas following a linear relationship with dose exposition (47). In the comparative analysis of RET rearrangements in sporadic and radiation-induced thyroid tumors performed by Nikiforov et al. (45), RET/PTC1 was shown to be the dominant type within sporadic carcinomas and was strongly related to the classic variant, while RET/PTC3 was predominant among radiation-induced carcinomas and more frequent in the solid PTC variant. These findings were confirmed by Tallini et al. (50) in a study including 201 sporadic PTCs and by Rabes et al. (48) and Thomas et al. (46) in two large studies of post-Chernobyl PTCs. Interestingly, Elisei et al. (18) and Bounacer et al. (20) showed that RET rearrangements occurred also in benign thyroid nodules with a history of irradiation, further confirming the direct correlation between radiation exposure and this genetic alteration. However, other unknown factors concur to the RET rearrangement, as 
Table 2 RET/PTC expression in PTC subtypes. Data are presented as sample numbers and (\%).

\begin{tabular}{lcll}
\hline References & cPTC & fvPTC & \multicolumn{1}{c}{ tcPTC } \\
\hline Basolo et al. $(77)^{\mathrm{a}}$ & $11 / 39(27.5)$ & $3 / 12(25)$ & $14 / 39(35.8)$ \\
Adeniran et al. $(78)^{\mathrm{b}}$ & $14 / 53(26)$ & $1 / 30(3)$ & $0 / 6$ \\
Tallini et al. $(50)^{\mathrm{a}}$ & $47 / 107(43)$ & $31 / 8(26)$ & \\
Nikiforov et al. $(45)^{\mathrm{a}}$ & $10 / 14(71)$ & $0 / 1$ & \\
Puxeddu et al. $(74)^{\mathrm{a}}$ & $4 / 15(27)$ & $7 / 25(28)$ & \\
Rhoden et al. $(75)^{\mathrm{c}}$ & $3 / 11(27)$ & $7 / 10(70)$ & \\
\hline
\end{tabular}

${ }^{\text {a }}$ Southern blot on RT-PCR.

${ }^{\mathrm{b}} \mathrm{RT}$-PCR visualized by ethidium bromide.

${ }^{\mathrm{c}}$ Real-time quantitative RT-PCR.

suggested by the lack of difference in the occurrence of RET/PTC in PTC between patients with and without a history of therapeutic irradiation (18). The application of the interphase FISH in post-Chernobyl papillary thyroid tumors led to the interesting observation that irradiated PTCs were composed of a mixture of cells with and without RET rearrangements (21). While the oncogenic potential of RET rearrangement has been demonstrated using transgenic mouse models, its subclonal occurrence suggests that in some instances it can be a secondary event in PTC development following radiation exposure.

The pathogenetic role of RET/PTC in spontaneous thyroid cancer is also supported by the observation of its frequent occurrence in micro-PTC. Fusco et al. (49) detected RET/PTC in microscopic papillary foci of thyroid nodules with borderline morphological features of malignancy. Tallini et al. (50) found a strong correlation between RET rearrangements and micro-carcinomas $(P<0.01)$, and accordingly, Sugg et al. (35) observed that RET/PTC was more prevalent in micro-PTCs than in clinically evident PTCs (77 vs 47\%). A different oncogenic potential of RET/PTC1 and RET/PTC3 has been proposed. Rabes et al. (48) observed that tumors carrying the RET/PTC3 rearrangement had a shorter latency and a more aggressive clinical behavior. RET/PTC 3 was more frequent than RET/PTC1 in tcPTC, an aggressive PTC variant, and its expression in transgenic mice generated solid tumor variants of thyroid cancer with more aggressive and metastatic behavior $(8,51)$.

\section{RET/PTC in benign diseases}

While initially RET/PTC was considered to be a specific marker for thyroid cancer, further studies reported the presence of this genetic alteration in different benign thyroid diseases. In this regard, the crucial factor has been represented by the introduction of highly sensitive detection methods that led to discover RET recombination in a higher percentage of PTCs and in a significant proportion of different benign thyroid lesions. The first paper reporting the presence of RET rearrangements in thyroid specimens of patients affected with HT was performed by Wirtschafter et al. (52). The authors detected RET/PTC in 95\% of samples by means of a highly sensitive RT-PCR using two rounds of amplification with at least 40 cycles per round. The same prevalence was confirmed in a further study by means of a highly sensitive Taqman PCR (53). Recently, Rhoden et al. (54) searched for RET/PTC in HT samples by means of different techniques. Analysis by dual-color FISH and by a combination of real-time PCR and lasercapture microdissection showed consistent results detecting RET/PTC in 68 and $62 \%$ respectively. The detection of RET rearrangements within HT samples might be related to the presence of occult PTCs in a relevant percentage of these patients, an hypothesis supported by several studies reporting the frequent occurrence of PTC in patients affected with HT $(52,55)$. The detection of RET/PTC in a broad percentage of both PTCs and HTs is quite interesting as these two conditions show many significant similarities. Indeed, follicular HT cells typically harbor cytological features and molecular markers similar to PTC and genetic alterations such as allelic DNA loss and karyotypical abnormalities (56-58). However, analysis by FISH and careful microscopic examination reported RET/PTC in rare follicular cells in the majority of thyroid glands with HT but excluded the possibility that these cells were collected from microscopic foci of PTC (54). Although the expression of RET/PTC in rare cells within HT could be an early step of carcinogenesis, no evidence is provided supporting a link with the development of clinically significant PTC, and the biological and clinical significance of this finding remains unclear.

Initially, the majority of studies excluded the occurrence of RET/PTC in benign nodules. Nevertheless, RET rearrangements have been sporadically reported in nodules classified as benign at histology. In 1991, Ishizaka et al. (17) detected for the first time RET/PTC in four of $19(21 \%)$ follicular adenomas by means of RT-PCR. A later study performed by Elisei et al. (18) by means of Southern blot on RT-PCR found RET rearrangements in $13.9 \%$ of naturally occurring benign nodules. In 2000, Cinti et al. (59) discovered three of 19 follicular adenomas harboring RET/PTC by means of FISH demonstrating that only $10-20 \%$ of cells carried the mutation. A recent study performed by Guerra et al. (24) further confirmed these findings as RET rearrangements were detected in $13.3 \%$ of nodules showing benign histology by means of Southern blotting after RT-PCR amplification. The latter study clearly demonstrated the relevance of the methodology applied as only one of the four positive cases was detected by application of RT-PCR amplification alone. Two studies performed a comparative analysis of RET recombination in benign lesions with and without radiation exposure. Bounacer et al. (20) detected RET rearrangements only in follicular adenomas (45\%) of patients with a history of external irradiation, but not in naturally occurring benign nodules. Elisei et al. (18) demonstrated a significantly higher occurrence of the rearrangement 
in benign nodules of patients exposed to irradiation than in spontaneous lesions. This evidence further confirms the strike association between radiation exposure and RET rearrangements also in benign thyroid lesions.

\section{Pathophysiological aspects of RET/PTC}

There are several lines of evidence pointing to RET/PTC as a driving event in thyroid carcinogenesis. The rat thyroid cells, $\mathrm{PCCl} 3$, change morphology, loose their differentiated functions, and are no longer TSH dependent for growth when stably transformed by RET/PTC3 (60). However, acute expression of RET/PTC is sufficient to block the expression of TSH receptor and generation of cAMP, but it is insufficient to allow cells to grow in the absence of TSH, suggesting that RET/PTC is a weak tumor-initiating factor and that secondary genetic or epigenetic changes are required for full transformation into a cancer cell (61). Transgenic mice expressing RET/PTC1 develop thyroid papillary carcinomas with features very similar to those shown by human PTC. These tumors are characterized by nuclear grooves and ground glass cells, slow growth rate, TSH responsiveness, continued expression of thyroglobulin, and loss of radioiodide-concentrating activity $(8,62)$. Similarly, RET/PTC3 transgenic mice develop thyroid hyperplasia and locally invasive solid subtype of PTC with lymph node metastasis (51). However, not all the RET/PTC transgenic animals develop thyroid cancer, and it appears only after a long latency period. This evidence suggests that other molecular events are required for the development of thyroid carcinomas. This concept is further supported by the finding that RET rearrangements can occur only in a fraction of the cells in some PTC, thus being a secondary event in these tumors, and by the presence of RET/PTC in sporadic cells in HT and benign nodules. Radiation exposure, cellular over-proliferation, production of free radicals, and chemokine secretion have been hypothesized to account for the occurrence of intrachromosomal rearrangements in these benign thyroid lesions (63).

The biological significance of RET/PTC in benign lesions is a challenging task. A recent study has tried to answer the question whether this oncogene changes the fate of benign nodules. Sapio et al. (26) searched for RET rearrangements in a cohort of benign thyroid nodules in patients subjected to a careful clinical and ultrasonographic follow-up for 3 years. The researchers did not find evidence of cancer development but demonstrated that nodules harboring RET/PTC grow more rapidly than those without the oncogene. This finding is consistent with the hypothesis that even the presence of a small portion of cells harboring RET/PTC may have biological and clinical consequences in benign nodules. While the mechanisms underlying the more rapid growth of these nodules remain unclear, it can be hypothesized that the pro-inflammatory transcriptional program activated by RET/PTC, including upregulation of various cytokines, chemokines, and their corresponding receptors, can stimulate thyroid cell proliferation through a autocrine/paracrine mechanism extended to the neighboring cells and involving a larger part of the nodule (64-66). More studies with longer follow-up are needed to clarify the clinical significance of low level of $R E T$ rearrangements in benign nodules.

\section{Application of RET/PTC testing in fine needle biopsy of thyroid nodules}

Since its discovery, RET/PTC was proposed as a hallmark of PTC useful to refine inconclusive cytology assessment of thyroid nodules. Although the amount of RNA obtained from fine needle biopsy is generally low, it does not appear to be a limitation, and in many studies, the survey of RET/PTC in cytology samples, even in needle washout, has been successfully performed. To use this oncogene as a diagnostic marker, it is essential to know its prevalence in malignant and benign lesions in a clinical setting, in order to determine the sensitivity and specificity of a RET/PTC-based assay. Unfortunately, the broad variability of RET/PTC prevalence in PTC reported in different studies is a strong limitation. This is in part due to geographic and environmental factors, but also to the application of different detection methods. Thus, the comparison of different studies is impaired by the lack of a unique and validated technique of detection. In the studies considered in Table 3, the oncogene was detected in cytology samples by means of different methods in 63 of 283 PTCs (22.3\%). Southern blot on RT-PCR was twice over more sensitive than RT-PCR alone (28.7 vs $11.5 \%$ ). In the study

Table 3 Survey of RET/PTC expression in cytology samples with definitive histology diagnosis. Data are presented as sample numbers and (\%). RT-PCR was visualized by ethidium bromide.

\begin{tabular}{|c|c|c|c|c|}
\hline & Histology & RT-PCR & $\begin{array}{l}\text { SB on } \\
\text { RT-PCR }\end{array}$ & Q-PCR \\
\hline Cheung et al. (14) & $\begin{array}{l}\text { PTC } \\
\text { B }\end{array}$ & & $\begin{array}{l}\text { 16/33 (48.5) } \\
0 / 39\end{array}$ & \\
\hline Domingues et al. (15) & $\begin{array}{l}\text { PTC } \\
\text { B }\end{array}$ & $\begin{array}{l}3 / 11(27.2) \\
1 / 11(9.1)\end{array}$ & & \\
\hline Sapio et al. (79) & $\begin{array}{l}\text { PTC } \\
\text { B }\end{array}$ & $\begin{array}{l}1 / 6(16.7) \\
0 / 72\end{array}$ & & \\
\hline Pizzolanti et al. (13) & $\begin{array}{l}\text { PTC } \\
\text { B }\end{array}$ & $\begin{array}{l}0 / 33 \\
0 / 32\end{array}$ & & \\
\hline Nikiforov et al. (16) & $\begin{array}{l}\text { PTC } \\
\text { B }\end{array}$ & & & $\begin{array}{l}5 / 40(12.5) \\
0 / 38\end{array}$ \\
\hline Cantara et al. (11) & $\begin{array}{l}\text { PTC } \\
\text { B }\end{array}$ & & $\begin{array}{l}11 / 74(14.9) \\
0 / 165\end{array}$ & \\
\hline Musholt et al. (80) & $\begin{array}{l}\text { PTC } \\
\text { B }\end{array}$ & $\begin{array}{l}2 / 22(9.1) \\
0 / 63\end{array}$ & & \\
\hline Guerra et al. (24) & $\begin{array}{l}\text { PTC } \\
\text { B }\end{array}$ & $\begin{array}{l}8 / 50(16.0) \\
1 / 30(3.3)\end{array}$ & $\begin{array}{l}18 / 50(36.0) \\
4 / 30(13.3)\end{array}$ & \\
\hline Overall & $\begin{array}{l}\text { PTC } \\
\text { B }\end{array}$ & $\begin{array}{l}14 / 122(11.5) \\
2 / 208(1.0)\end{array}$ & $\begin{array}{l}45 / 157(28.7) \\
4 / 234(1.71)\end{array}$ & $\begin{array}{l}5 / 40(12.5) \\
0 / 38\end{array}$ \\
\hline
\end{tabular}

PTC, papillary thyroid carcinoma; B, benign nodules; SB on RT-PCR, RT-PCR visualized by Southern blot; Q-PCR, real-time quantitative PCR. 
by Cantara et al. (11), searching for RET/PTC allowed to correctly diagnose two PTCs of 87 nodules classified as benign at cytology and two PTCs of 41 in the indeterminate category. In two other studies, two PTCs of 52 nodules and nine of 23 were identified in the indeterminate category by RET/PTC detection $(14,16)$. These results suggest that searching for RET/PTC can be used as a complementary approach to FNAC, increasing the overall sensitivity of a preoperative cytological diagnosis.

In most of the studies, BRAF mutation was also investigated, demonstrating only a small overlap between the two oncogenes so that searching for both markers further improves the sensitivity of molecular diagnosis. In the study by Pizzolanti et al., the sensitivity of a molecular assay using $B R A F^{\mathrm{V} 600 \mathrm{E}}$ alone was $69 \%$ and increased to $78 \%$ in combination with RET/PTC (16). Similarly, in the studies by Nikiforov et al. (16) and Cantara et al. (11) searching for both oncogenes increased the sensitivity from 45.0 to $57.5 \%$ and from 42.3 to $56.4 \%$ respectively $(11,13)$. Noteworthy in these two studies, is the detection of RET/PTC disclosed two false negatives over 99 benign FNACs and identified five PTCs over 146 indeterminate or inadequate FNACs.

Unlike $B R A F^{\mathrm{V} 600 \mathrm{E}}$, RET/PTC is also sporadically detected in non-malignant thyroid lesions at low expression level. By means of Southern blot on RT-PCR, RET rearrangement was found in $13.3 \%$ of cytology aspirates from nodules classified as benign at histology after careful microscopic observation that did not disclose microscopic foci of malignancy (24). In the same study, only one of the four positive cases was detected by application of RT-PCR amplification alone, demonstrating that the sensitivity of the detection method is a crucial factor. The finding of RET/PTC in non-malignant nodules renders its application in a diagnostic assay more problematic.

\section{Conclusions}

FNAC is the gold standard for the differential diagnosis of thyroid nodules. Unfortunately, inconclusive results present a large gray zone even for skilled pathologists. The discovery of genetic mutations involved in the pathogenesis of thyroid tumors has provided the basis for further improvements of the pre-surgical diagnostic methods. The most extensively studied mutation in this diagnostic context is $B R A F^{V 600 E}$ (67). Because this highly specific PTC marker is expressed only in about half of PTCs, more cancer markers are needed. Its demonstrated pathogenetic role, its prevalence of about $20 \%$, and its low overlapping with $B R A F^{\mathrm{V} 600 \mathrm{E}}$ have made RET/PTC one of the most promising genetic alteration in a multiple marker diagnostic assay. However, the initial enthusiasm has been tempered by the demonstration that this oncogene is also found in non-malignant thyroid nodules. The biological and clinical significance of $R E T / P T C$ in benign thyroid lesions is still controversial. FISH analysis demonstrated that in HT, in adenomas, and also in a significant percentage of PTCs, RET/PTC is present as oligoclonal occurrence $(21,22,54,59)$. The expression of RET/PTC in HT can be explained as an event secondary to chemokine stimulation induced by the large lymphoid infiltration present in this disease. Similarly, chronic stimulation by lymphoid infiltration, radiation exposure, or other factors in benign and malignant nodules could be responsible for the occurrence of RET rearrangements in sporadic cells. Although several observations have associated HT to thyroid tumors, including the occurrence of cytological alterations similar to those found in PTC and an increase in the risk for papillary carcinoma, to date there are no evidence supporting the concept that RET/PTC-expressing HT is a PTC precursor.

In a very recent study, Sapio et al. (26) followed for 3 years 19 nodules diagnosed as benign at FNAC that harbored RET/PTC1 or RET/PTC3. Clinical and ultrasound examination did not provide evidence for a malignant transformation, and the final histopathology of three of these nodules was benign hyperplastic nodules. Of note is that RET/PTC-positive nodules displayed a fourfold faster growth with respect to their RET/PTC-negative counterparts. Thus, while at the moment a nodule with benign cytology and RET rearrangement disclosed by means of Southern blot on RT-PCR must be considered benign in nature, it should be subjected to a careful follow-up for its propensity to a fast enlargement. Searching for RET/PTC by highly sensitive methods might be useful in choosing the most appropriate and timely therapeutic option for benign thyroid nodules.

At the same time, highly sensitive methods are not appropriate to distinguish between benign and malignant nodules in inconclusive cytology. Searching for RET/PTC by a less sensitive method may have the drawback of leaving some PTCs undiagnosed but has the advantage of reducing false positive findings. Indeed, while sporadic cells harboring a RET rearrangement can be present in benign nodules, its clonal occurrence is exclusive to PTC. Hence, the less sensitive RT-PCR is more suitable for diagnostic purposes than Southern blot on RT-PCR. Rhoden et al. (54) demonstrated the possibility to distinguish between HT and PTC by RET/PTC in quantitative methods. Because RET/PTC cannot be considered as an absolute marker of PTC, its application for diagnostic purposes in cytology samples is limited to less sensitive methods or must wait for a precise cutoff in a quantitative assay, fixed in a clinical setting. Until that time, FISH analysis remains the most appropriate means to detect the clonal occurrence of RET/PTC, suitable to refine inconclusive cytology. Future studies with a long follow-up of benign nodules will clarify the clinical significance of low level of RET rearrangements. 


\section{Declaration of interest}

The authors declare that there is no conflict of interest that could be perceived as prejudicing the impartiality of the review reported.

\section{Funding}

This work has been supported in part by Ministero dell'Istruzione, dell'Università e della Ricerca (to M Vitale).

\section{References}

1 Gharib H \& Goellner JR. Fine-needle aspiration biopsy of the thyroid: an appraisal. Annals of Internal Medicine $1993 \mathbf{1 1 8}$ 282-289.

2 Baloch ZW \& LiVolsi VA. Fine-needle aspiration of thyroid nodules: past, present, and future. Endocrine Practice 200410 234-241.

3 Vitale M, Bassi V, Illario M, Fenzi G, Casamassima A \& Rossi G. Loss of polarity and de novo expression of the beta 1 family of integrins in thyroid tumors. International Journal of Cancer $1994 \mathbf{5 9}$ 185-190. (doi:10.1002/ijc.2910590208)

4 Sapio MR, Guerra A, Posca D, Limone PP, Deandrea M, Motta M, Troncone G, Caleo A, Vallefuoco P, Rossi G, Fenzi G \& Vitale M. Combined analysis of galectin-3 and BRAF ${ }^{\mathrm{V} 600 \mathrm{E}}$ improves the accuracy of fine-needle aspiration biopsy with cytological findings suspicious for papillary thyroid carcinoma. Endocrine-Related Cancer 2007 14 1089-1097. (doi:10.1677/ERC-07-0147)

5 Prasad ML, Pellegata NS, Huang Y, Nagaraja HN, de la Chapelle A \& Kloos RT. Galectin-3, fibronectin-1, CITED-1, HBME1 and cytokeratin-19 immunohistochemistry is useful for the differential diagnosis of thyroid tumors. Modern Pathology 200518 48-57. (doi:10.1038/modpathol.3800235)

6 Vitale M, Bassi V, Fenzi G, Macchia PE, Salzano S \& Rossi G. Integrin expression in thyroid cells from normal glands and nodular goiters. Journal of Clinical Endocrinology and Metabolism 199376 1575-1579. (doi:10.1210/jc.76.6.1575)

7 Fusco A, Grieco M, Santoro M, Berlingieri MT, Pilotti S, Pierotti MA, Della Porta G \& Vecchio G. A new oncogene in human thyroid papillary carcinomas and their lymph-nodal metastases. Nature $1987 \quad 328 \quad 170-172 . \quad$ (doi:10.1038/ 328170a0)

8 Santoro M, Chiappetta G, Cerrato A, Salvatore D, Zhang L, Manzo G, Picone A, Portella G, Santelli G, Vecchio G \& Fusco A. Development of thyroid papillary carcinomas secondary to tissuespecific expression of the RET/PTC1 oncogene in transgenic mice. Oncogene 199612 1821-1826.

9 Viglietto G, Chiappetta G, Martinez-Tello FJ, Fukunaga FH, Tallini G, Rigopoulou D, Visconti R, Mastro A, Santoro M \& Fusco A. RET/PTC oncogene activation is an early event in thyroid carcinogenesis. Oncogene 199511 1207-1210.

10 Santoro M, Carlomagno F, Hay ID, Herrmann MA, Grieco M, Melillo R, Pierotti MA, Bongarzone I, Della Porta G, Berger N, Peix JL, Paulin C, Fabien N, Vecchio G, Jenkins RB \& Fusco A. RET oncogene activation in human thyroid neoplasms is restricted to the papillary cancer subtype. Journal of Clinical Investigation 199289 1517-1522. (doi:10.1172/JCI115743)

11 Cantara S, Capezzone M, Marchisotta S, Capuano S, Busonero G, Toti P, Di Santo A, Caruso G, Carli AF, Brilli L, Montanaro A \& Pacini F. Impact of proto-oncogene mutation detection in cytological specimens from thyroid nodules improves the diagnostic accuracy of cytology. Journal of Clinical Endocrinology and Metabolism 2010 95 1365-1369. (doi:10.1210/jc.2009-2103)

12 Salvatore G, Giannini R, Faviana P, Caleo A, Migliaccio I, Fagin JA, Nikiforov YE, Troncone G, Palombini L, Basolo F \& Santoro M. Analysis of BRAF point mutation and RET/PTC rearrangement refines the fine-needle aspiration diagnosis of papillary thyroid carcinoma. Journal of Clinical Endocrinology and Metabolism 2004 89 5175-5180. (doi:10.1210/jc.2003-032221)
13 Pizzolanti G, Russo L, Richiusa P, Bronte V, Nuara RB, Rodolico V, Amato MC, Smeraldi L, Sisto PS, Nucera M, Bommarito A, Citarrella R, Lo Coco R, Cabibi D, Lo Coco A, Frasca F, Gulotta G, Latteri MA, Modica G, Galluzzo A \& Giordano C. Fine-needle aspiration molecular analysis for the diagnosis of papillary thyroid carcinoma through $\mathrm{BRAF}^{\mathrm{V600E}}$ mutation and RET/PTC rearrangement. Thyroid $2007 \quad 17$ 1109-1115. (doi:10.1089/ thy.2007.0008)

14 Cheung CC, Carydis B, Ezzat S, Bedard YC \& Asa SL. Analysis of RET/PTC gene rearrangements refines the fine needle aspiration diagnosis of thyroid cancer. Journal of Clinical Endocrinology and Metabolism 200186 2187-2190. (doi:10.1210/jc.86.5.2187)

15 Domingues R, Mendonca E, Sobrinho L \& Bugalho MJ. Searching for RET/PTC rearrangements and BRAF ${ }^{\mathrm{V} 59 \mathrm{E}}$ mutation in thyroid aspirates might contribute to establish a preoperative diagnosis of papillary thyroid carcinoma. Cytopathology $2005 \mathbf{1 6}$ 27-31. (doi:10.1111/j.1365-2303.2004.00223.x)

16 Nikiforov YE, Steward DL, Robinson-Smith TM, Haugen BR, Klopper JP, Zhu Z, Fagin JA, Falciglia M, Weber K \& Nikiforova MN. Molecular testing for mutations in improving the fine-needle aspiration diagnosis of thyroid nodules. Journal of Clinical Endocrinology and Metabolism 200994 2092-2098. (doi:10. 1210/jc.2009-0247)

17 Ishizaka Y, Kobayashi S, Ushijima T, Hirohashi S, Sugimura T \& Nagao M. Detection of RetTPC/PTC transcripts in thyroid adenomas and adenomatous goiter by an RT-PCR method. Oncogene 19916 1667-1672.

18 Elisei R, Romei C, Vorontsova T, Cosci B, Veremeychik V, Kuchinskaya E, Basolo F, Demidchik EP, Miccoli P, Pinchera A \& Pacini F. RET/PTC rearrangements in thyroid nodules: studies in irradiated and not irradiated, malignant and benign thyroid lesions in children and adults. Journal of Clinical Endocrinology and Metabolism 200186 3211-3216. (doi:10.1210/jc.86.7.3211)

19 Nikiforova MN, Caudill CM, Biddinger P \& Nikiforov YE. Prevalence of RET/PTC rearrangements in Hashimoto's thyroiditis and papillary thyroid carcinomas. International Journal of Surgical Pathology 200210 15-22. (doi:10.1177/ 106689690201000104)

20 Bounacer A, Wicker R, Caillou B, Cailleux AF, Sarasin A, Schlumberger M \& Suarez HG. High prevalence of activating RET proto-oncogene rearrangements, in thyroid tumors from patients who had received external radiation. Oncogene 199715 1263-1273. (doi:10.1038/sj.onc.1200206)

21 Unger K, Zitzelsberger H, Salvatore G, Santoro M, Bogdanova T, Braselmann H, Kastner P, Zurnadzhy L, Tronko N, Hutzler P \& Thomas G. Heterogeneity in the distribution of RET/PTC rearrangements within individual post-Chernobyl papillary thyroid carcinomas. Journal of Clinical Endocrinology and Metabolism 200489 4272-4279. (doi:10.1210/jc.2003-031870)

22 Zhu Z, Ciampi R, Nikiforova MN, Gandhi M \& Nikiforov YE. Prevalence of RET/PTC rearrangements in thyroid papillary carcinomas: effects of the detection methods and genetic heterogeneity. Journal of Clinical Endocrinology and Metabolism 200691 3603-3610. (doi:10.1210/jc.2006-1006)

23 Tallini G \& Asa SL. RET oncogene activation in papillary thyroid carcinoma. Advances in Anatomic Pathology 20018 345-354. (doi:10.1097/00125480-200111000-00005)

24 Guerra A, Sapio MR, Marotta V, Campanile E, Moretti MI, Deandrea M, Motta M, Limone PP, Fenzi G, Rossi G \& Vitale M. Prevalence of RET/PTC rearrangement in benign and malignant thyroid nodules and its clinical application. Endocrine Journal 2011 58 31-38. (doi:10.1507/endocrj.K10E-260)

25 Marotta V, Guerra A, Sapio MR, Campanile E, Motta M, Fenzi G, Rossi G \& Vitale M. Growing thyroid nodules with benign histology and RET rearrangement. Endocrine Journal $2010 \mathbf{5 7}$ 1081-1087. (doi:10.1507/endocrj.K10E-229)

26 Sapio MR, Guerra A, Marotta V, Campanile E, Formisano R, Deandrea M, Motta M, Limone PP, Fenzi G, Rossi G \& Vitale M. High growth rate of benign thyroid nodules bearing RET/PTC rearrangements. Journal of Clinical Endocrinology and Metabolism 201196 E916-E919. (doi:10.1210/jc.2010-1599) 
27 Takahashi M, Ritz J \& Cooper GM. Activation of a novel human transforming gene, RET, by DNA rearrangement. Cell 198542 581-588. (doi:10.1016/0092-8674(85)90115-1)

28 Durbec PL, Larsson-Blomberg LB, Schuchardt A, Costantini F \& Pachnis V. Common origin and developmental dependence on c-RET of subsets of enteric and sympathetic neuroblasts. Development 1996122 349-358.

29 Schuchardt A, D’Agati V, Larsson-Blomberg L, Costantini F \& Pachnis V. Defects in the kidney and enteric nervous system of mice lacking the tyrosine kinase receptor Ret. Nature 1994367 380-383. (doi:10.1038/367380a0)

30 Knowles PP, Murray-Rust J, Kjaer S, Scott RP, Hanrahan S, Santoro M, Ibanez CF \& McDonald NQ. Structure and chemical inhibition of the RET tyrosine kinase domain. Journal of Biological Chemistry 2006281 33577-33587. (doi:10.1074/ jbc.M605604200)

31 Bunone G, Uggeri M, Mondellini P, Pierotti MA \& Bongarzone I. RET receptor expression in thyroid follicular epithelial cell-derived tumors. Cancer Research 200060 2845-2849.

32 Santoro M, Melillo RM \& Fusco A. RET/PTC activation in papillary thyroid carcinoma: European Journal of Endocrinology Prize Lecture. European Journal of Endocrinology 2006155 645-653. (doi:10.1530/eje.1.02289)

33 Santoro M, Dathan NA, Berlingieri MT, Bongarzone I, Paulin C, Grieco M, Pierotti MA, Vecchio G \& Fusco A. Molecular characterization of RET/PTC3; a novel rearranged version of the RET proto-oncogene in a human thyroid papillary carcinoma. Oncogene 19949 509-516.

34 Salvatore D, Barone MV, Salvatore G, Melillo RM, Chiappetta G, Mineo A, Fenzi G, Vecchio G, Fusco A \& Santoro M. Tyrosines 1015 and 1062 are in vivo autophosphorylation sites in RET and RET-derived oncoproteins. Journal of Clinical Endocrinology and Metabolism 2000 85 3898-3907. (doi:10.1210/jc.85.10.3898)

35 Sugg SL, Ezzat S, Rosen IB, Freeman JL \& Asa SL. Distinct multiple RET/PTC gene rearrangements in multifocal papillary thyroid neoplasia. Journal of Clinical Endocrinology and Metabolism 199883 4116-4122. (doi:10.1210/jc.83.11.4116)

36 Xu X, Quiros RM, Gattuso P, Ain KB \& Prinz RA. High prevalence of BRAF gene mutation in papillary thyroid carcinomas and thyroid tumor cell lines. Cancer Research $2003 \mathbf{6 3} 4561-4567$.

37 El-Abdallah AA \& Junaid TA. Overexpression of wild-type c-RET and zero prevalence of RET/PTC rearrangements are associated with papillary thyroid cancer (PTC) in Kuwait. Experimental and Molecular Pathology 201190 61-65. (doi:10.1016/j.yexmp. 2010.10.002)

38 Hieber L, Huber R, Bauer V, Schaffner Q, Braselmann H, Thomas G, Bogdanova T \& Zitzelsberger H. Chromosomal rearrangements in post-Chernobyl papillary thyroid carcinomas: evaluation by spectral karyotyping and automated interphase FISH. Journal of Biomedicine E Biotechnology 20112011693691. (doi:10.1155/2011/693691)

39 Nikiforova MN, Stringer JR, Blough R, Medvedovic M, Fagin JA \& Nikiforov YE. Proximity of chromosomal loci that participate in radiation-induced rearrangements in human cells. Science 2000 290 138-141. (doi:10.1126/science.290.5489.138)

40 DeLellis RA \& Williams D. Thyroid and parathyroid tumors. In World Health Organization Classification of Tumours. Pathology and Genetics. Tumours of Endocrine organs, pp 51-56. Eds RA DeLellis, RV Lloyd \& PU Heitz, Geneva: WHO Press, 2003.

41 Cheung CC, Ezzat S, Ramyar L, Freeman JL \& Asa SL. Molecular basis off hurthle cell papillary thyroid carcinoma. Journal of Clinical Endocrinology and Metabolism 200085 878-882. (doi:10.1210/ jc. 85.2.878)

42 Chiappetta G, Toti P, Cetta F, Giuliano A, Pentimalli F, Amendola I, Lazzi S, Monaco M, Mazzuchelli L, Tosi P, Santoro M \& Fusco A. The RET/PTC oncogene is frequently activated in oncocytic thyroid tumors (Hurthle cell adenomas and carcinomas), but not in oncocytic hyperplastic lesions. Journal of Clinical Endocrinology and Metabolism 2002 87 364-369. (doi:10.1210/jc.87.1.364)

43 Cetta F, Chiappetta G, Melillo RM, Petracci M, Montalto G, Santoro M \& Fusco A. The RET/PTC1 oncogene is activated in familial adenomatous polyposis-associated thyroid papillary carcinomas. Journal of Clinical Endocrinology and Metabolism 199883 1003-1006. (doi:10.1210/jc.83.3.1003)

44 Papotti M, Volante M, Giuliano A, Fassina A, Fusco A, Bussolati G, Santoro M \& Chiappetta G. RET/PTC activation in hyalinizing trabecular tumors of the thyroid. American Journal of Surgical Pathology 200024 1615-1621. (doi:10.1097/00000478200012000-00004)

45 Nikiforov YE, Rowland JM, Bove KE, Monforte-Munoz H \& Fagin JA. Distinct pattern of RET oncogene rearrangements in morphological variants of radiation-induced and sporadic thyroid papillary carcinomas in children. Cancer Research $1997 \mathbf{5 7}$ 1690-1694.

46 Thomas GA, Bunnell H, Cook HA, Williams ED, Nerovnya A Cherstvoy ED, Tronko ND, Bogdanova TI, Chiappetta G, Viglietto G, Pentimalli F, Salvatore G, Fusco A, Santoro M \& Vecchio G. High prevalence of RET/PTC rearrangements in Ukrainian and Belarussian post-Chernobyl thyroid papillary carcinomas: a strong correlation between RET/PTC3 and the solid-follicular variant. Journal of Clinical Endocrinology and Metabolism $1999 \mathbf{8 4} 4232-4238$. (doi:10.1210/jc.84.11.4232)

47 Jacob P, Kenigsberg Y, Zvonova I, Goulko G, Buglova E, Heidenreich WF, Golovneva A, Bratilova AA, Drozdovitch V, Kruk J, Pochtennaja GT, Balonov M, Demidchik EP \& Paretzke HG. Childhood exposure due to the Chernobyl accident and thyroid cancer risk in contaminated areas of Belarus and Russia. British Journal of Cancer $1999 \mathbf{8 0}$ 1461-1469. (doi:10.1038/sj.bjc. 6690545)

48 Rabes HM, Demidchik EP, Sidorow JD, Lengfelder E, Beimfohr C. Hoelzel D \& Klugbauer S. Pattern of radiation-induced RET and NTRK1 rearrangements in 191 post-Chernobyl papillary thyroid carcinomas: biological, phenotypic, and clinical implications. Clinical Cancer Research 20006 1093-1103.

49 Fusco A, Chiappetta G, Hui P, Garcia-Rostan G, Golden L, Kinder BK, Dillon DA, Giuliano A, Cirafici AM, Santoro M, Rosai J \& Tallini G. Assessment of RET/PTC oncogene activation and clonality in thyroid nodules with incomplete morphological evidence of papillary carcinoma: a search for the early precursors of papillary cancer. American Journal of Pathology $2002 \mathbf{1 6 0}$ 2157-2167. (doi:10.1016/S0002-9440(10)61164-9)

50 Tallini G, Santoro M, Helie M, Carlomagno F, Salvatore G, Chiappetta G, Carcangiu ML \& Fusco A. RET/PTC oncogene activation defines a subset of papillary thyroid carcinomas lacking evidence of progression to poorly differentiated or undifferentiated tumor phenotypes. Clinical Cancer Research 1998 4 287-294.

51 Powell DJ Jr, Russell J, Nibu K, Li G, Rhee E, Liao M, Goldstein M, Keane WM, Santoro M, Fusco A \& Rothstein JL. The RET/PTC3 oncogene: metastatic solid-type papillary carcinomas in murine thyroids. Cancer Research $1998 \mathbf{5 8}$ 5523-5528.

52 Wirtschafter A, Schmidt R, Rosen D, Kundu N, Santoro M, Fusco A, Multhaupt H, Atkins JP, Rosen MR, Keane WM \& Rothstein JL. Expression of the RET/PTC fusion gene as a marker for papillary carcinoma in Hashimoto's thyroiditis. Laryngoscope 1997107 95-100. (doi:10.1097/00005537-19970100000019)

53 Sheils OM, O'Eary JJ, Uhlmann V, Lattich K \& Sweeney EC. RET/PTC-1 activation in Hashimoto thyroiditis. International Journal of Surgical Pathology 20008 185-189. (doi:10.1177/ $106689690000800305)$

54 Rhoden KJ, Unger K, Salvatore G, Yilmaz Y, Vovk V, Chiappetta G, Oumsiyeh MB, Rothstein JL, Fusco A, Santoro M, Zitzelsberger H \& Tallini G. RET/papillary thyroid cancer rearrangement in nonneoplastic thyrocytes: follicular cells of Hashimoto's thyroiditis share low-level recombination events with a subset of papillary carcinoma. Journal of Clinical Endocrinology and Metabolism 200691 2414-2423. (doi:10.1210/jc.2006-0240)

55 Dailey ME, Lindsay S \& Skahen R. Relation of thyroid neoplasms to Hashimoto disease of the thyroid gland. A.M.A. Archives of Surgery 195570 291-297.

56 Gasbarri A, Sciacchitano S, Marasco A, Papotti M, Di Napoli A, Marzullo A, Yushkov P, Ruco L \& Bartolazzi A. Detection and 
molecular characterisation of thyroid cancer precursor lesions in a specific subset of Hashimoto's thyroiditis. British Journal of Cancer 200491 1096-1104.

57 Hunt JL, Baloch ZW, Barnes L, Swalsky PA, Trusky CL, Sesatomi E, Finkelstein S \& LiVolsi VA. Loss of heterozygosity mutations of tumor suppressor genes in cytologically atypical areas in chronic lymphocytic thyroiditis. Endocrine Pathology 200213 321-330. (doi:10.1385/EP:13:4:321)

58 Prasad ML, Huang Y, Pellegata NS, de la Chapelle A \& Kloos RT. Hashimoto's thyroiditis with papillary thyroid carcinoma (PTC)-like nuclear alterations express molecular markers of PTC. Histopathology $2004 \quad 45$ 39-46. (doi:10.1111/j.1365-2559. 2004.01876.x)

59 Cinti R, Yin L, Ilc K, Berger N, Basolo F, Cuccato S, Giannini R, Torre G, Miccoli P, Amati P, Romeo G \& Corvi R. RET rearrangements in papillary thyroid carcinomas and adenomas detected by interphase FISH. Cytogenetics and Cell Genetics 2000 88 56-61. (doi:10.1159/000015485)

60 Santoro M, Melillo RM, Grieco M, Berlingieri MT, Vecchio G \& Fusco A. The TRK and RET tyrosine kinase oncogenes cooperate with ras in the neoplastic transformation of a rat thyroid epithelial cell line. Cell Growth \& Differentiation 19934 77-84.

61 Wang J, Knauf JA, Basu S, Puxeddu E, Kuroda H, Santoro M, Fusco A \& Fagin JA. Conditional expression of RET/PTC induces a weak oncogenic drive in thyroid PCCL3 cells and inhibits thyrotropin action at multiple levels. Molecular Endocrinology 200317 1425-1436. (doi:10.1210/me.2003-0041)

62 Jhiang SM, Cho JY, Furminger TL, Sagartz JE, Tong Q, Capen CC \& Mazzaferri EL. Thyroid carcinomas in RET/PTC transgenic mice. Recent Results in Cancer Research 1998154 265-270.

63 Gandhi M, Medvedovic M, Stringer JR \& Nikiforov YE. Interphase chromosome folding determines spatial proximity of genes participating in carcinogenic RET/PTC rearrangements. Oncogene 200625 2360-2366. (doi:10.1038/sj.onc.1209268)

64 Melillo RM, Castellone MD, Guarino V, De Falco V, Cirafici AM, Salvatore G, Caiazzo F, Basolo F, Giannini R, Kruhoffer M, Orntoft T, Fusco A \& Santoro M. The RET/PTC-RAS-BRAF linear signaling cascade mediates the motile and mitogenic phenotype of thyroid cancer cells. Journal of Clinical Investigation 2005115 1068-1081. (doi:10.1172/JCI22758)

65 Borrello MG, Alberti L, Fischer A, Degl'innocenti D, Ferrario C, Gariboldi M, Marchesi F, Allavena P, Greco A, Collini P, Pilotti S, Cassinelli G, Bressan P, Fugazzola L, Mantovani A \& Pierotti MA. Induction of a proinflammatory program in normal human thyrocytes by the RET/PTC1 oncogene. PNAS $2005 \mathbf{1 0 2}$ 14825-14830. (doi:10.1073/pnas.0503039102)

66 Vitale M, Di Matola T, Fenzi G, Illario M \& Rossi G. Fibronectin is required to prevent thyroid cell apoptosis through an integrinmediated adhesion mechanism. Journal of Clinical Endocrinology and Metabolism 199883 3673-3680. (doi:10.1210/jc.83.10. 3673)

67 Nucera C, Nehs MA, Nagarkatti SS, Sadow PM, Mekel M, Fischer AH, Lin PS, Bollag GE, Lawler J, Hodin RA \& Parangi S. Targeting BRAF ${ }^{\mathrm{V} 600 \mathrm{E}}$ with PLX4720 displays potent antimigratory and anti-invasive activity in preclinical models of human thyroid cancer. Oncologist 201116 296-309. (doi:10.1634/ theoncologist.2010-0317)

68 Zou M, Shi Y \& Farid NR. Low rate of RET proto-oncogene activation (PTC/RetTPC) in papillary thyroid carcinomas from Saudi Arabia. Cancer 199473 176-180. (doi:10.1002/1097-01 42(19940101)73:1<176::AID-CNCR2820730130>3.0.CO;2-T)

69 Lam AK, Montone KT, Nolan KA \& Livolsi VA. RET oncogene activation in papillary thyroid carcinoma: prevalence and implication on the histological parameters. Human Pathology 199829 565-568. (doi:10.1016/S0046-8177(98)80004-X)
70 Mayr B, Potter E, Goretzki P, Ruschoff J, Dietmaier W, Hoang-Vu C, Dralle H \& Brabant G. Expression of RET/PTC1, -2, -3, -delta 3 and -4 in German papillary thyroid carcinoma. British Journal of Cancer 199877 903-906. (doi:10.1038/bjc.1998.149)

71 Sheils OM, O'Leary JJ \& Sweeney EC. Assessment of RET/PTC-1 rearrangements in neoplastic thyroid tissue using TaqMan RT-PCR. Journal of Pathology 2000192 32-36. (doi:10.1002/ 1096-9896(2000)9999:9999<::AID-PATH668> 3.0.CO;2-F)

72 Fenton CL, Lukes Y, Nicholson D, Dinauer CA, Francis GL \& Tuttle RM. The RET/PTC mutations are common in sporadic papillary thyroid carcinoma of children and young adults. Journal of Clinical Endocrinology and Metabolism $2000 \mathbf{8 5}$ 1170-1175. (doi:10.1210/jc.85.3.1170)

73 Chua EL, Wu WM, Tran KT, McCarthy SW, Lauer CS, Dubourdieu D, Packham N, O'Brien CJ, Turtle JR \& Dong Q. Prevalence and distribution of RET/PTC 1, 2, and 3 in papillary thyroid carcinoma in New Caledonia and Australia. Journal of Clinical Endocrinology and Metabolism $2000 \quad 85$ 2733-2739. (doi:10.1210/jc.85.8.2733)

74 Puxeddu E, Moretti S, Giannico A, Martinelli M, Marino C, Avenia N, Cristofani R, Farabi R, Reboldi G, Ribacchi R, Pontecorvi A \& Santeusanio F. RET/PTC activation does not influence clinical and pathological features of adult papillary thyroid carcinomas. European Journal of Endocrinology $2003 \mathbf{1 4 8}$ 505-513. (doi:10.1530/eje.0.1480505)

75 Rhoden KJ, Johnson C, Brandao G, Howe JG, Smith BR \& Tallini G. Real-time quantitative RT-PCR identifies distinct c-RET, RET/ PTC1 and RET/PTC3 expression patterns in papillary thyroid carcinoma. Laboratory Investigation; A Journal of Technical Methods and Pathology 200484 1557-1570. (doi:10.1038/labinvest. 3700198)

76 Frasca F, Nucera C, Pellegriti G, Gangemi P, Attard M, Stella M, Loda M, Vella V, Giordano C, Trimarchi F, Mazzon E, Belfiore A \& Vigneri R. BRAF(V600E) mutation and the biology of papillary thyroid cancer. Endocrine-Related Cancer 200815 191-205. (doi:10.1677/ERC-07-0212)

77 Basolo F, Giannini R, Monaco C, Melillo RM, Carlomagno F, Pancrazi M, Salvatore G, Chiappetta G, Pacini F, Elisei R, Miccoli P, Pinchera A, Fusco A \& Santoro M. Potent mitogenicity of the RET/ PTC3 oncogene correlates with its prevalence in tall-cell variant of papillary thyroid carcinoma. American Journal of Pathology 2002 160 247-254. (doi:10.1016/S0002-9440(10)64368-4)

78 Adeniran AJ, Zhu Z, Gandhi M, Steward DL, Fidler JP, Giordano TJ, Biddinger PW \& Nikiforov YE. Correlation between genetic alterations and microscopic features, clinical manifestations, and prognostic characteristics of thyroid papillary carcinomas. American Journal of Surgical Pathology 200630 216-222. (doi:10. 1097/01.pas.0000176432.73455.1b)

79 Sapio MR, Posca D, Raggioli A, Guerra A, Marotta V, Deandrea M, Motta M, Limone PP, Troncone G, Caleo A, Rossi G, Fenzi G \& Vitale M. Detection of RET/PTC, TRK and BRAF mutations in preoperative diagnosis of thyroid nodules with indeterminate cytological findings. Clinical Endocrinology 200766 678-683. (doi:10.1111/j.1365-2265.2007.02800.x)

80 Musholt TJ, Fottner C, Weber MM, Eichhorn W, Pohlenz J, Musholt PB, Springer E \& Schad A. Detection of papillary thyroid carcinoma by analysis of BRAF and RET/PTC1 mutations in fine-needle aspiration biopsies of thyroid nodules. World Journal of Surgery $2010 \mathbf{3 4} 2595-2603$. (doi:10.1007/s00268010-0729-4)

Received 26 April 2011

Revised version received 6 July 2011

Accepted 12 July 2011 